\title{
Understanding Mass Persuasion and Propaganda in Malaysian Newspaper Crime Images using the Model of Jowet and Donnell Model
}

\author{
Farihan Zahari', Aidah Alias ${ }^{1}$, Mustaffa Halabi Azahari² \\ ${ }^{1}$ Faculty of Art and Design, Universiti Teknologi MARA, 78000 Alor Gajah Melaka, Malaysia \\ ${ }^{2}$ School of Creative Industry Management and Perform, Universiti Utara Malaysia, 06010 Sintok, Kedah, Malaysia \\ farih491@uitm.edu.my, aidah637@uitm.edu.my, mustaffaazahari@gmail.com \\ Tel: +6010-2264393
}

\begin{abstract}
Propaganda and persuasion are synonymous with media at present, a form of communication that used and found in the media: television, internet, radio, newspapers, magazines, and so on. This research focuses on Crime Image in Malaysian Primetime Newspaper. This paper's objective is to understand the Mass Persuasion and propaganda in Malaysian Newspaper: Crime images by using the Jowett and Donnell models as a guideline. Persuasion and propaganda are two essential elements in a criminal image that is displayed in the newspaper as can to attract the attention and interest of society and its general readers. In conclusion; this paper is to gather information and to understand the Mass Persuasion and propaganda in Malaysian Newspaper: Crime images by using the Jowett and Donnell models as a guideline.
\end{abstract}

Keywords: Mass Persuasion, Propaganda, Crime Image, Jowett and Donnell Model

eISSN: 2398-4287 @ 2020. The Authors. Published for AMER ABRA cE-Bs by e-International Publishing House, Ltd., UK. This is an open access article under the CC BYNC-ND license (http://creativecommons.org/licenses/by-nc-nd/4.0/). Peer-review under responsibility of AMER (Association of Malaysian Environment-Behaviour Researchers), ABRA (Association of Behavioural Researchers on Asians) and cE-Bs (Centre for Environment-Behaviour Studies), Faculty of Architecture, Planning \& Surveying, Universiti Teknologi MARA, Malaysia.

DOI: https://doi.org/10.21834/ebpj.v5iSI1.2310

\subsection{Introduction}

Malaysia is often preoccupied with social issues of concern. Social issues of concern often preoccupy Malaysia. Social problems among adolescents today are alarming as they contribute to the crime scene. The proof that almost every day in the newspapers is presented with news on the crime scene involving adolescents. The crime involves fights that lead to killing, baby disassembly, and so forth. According to Kamal Effendi Hashim, this crime is classified as a criminal body. Index crimes are divided into two: the crime of property and property crime. Crime against physical body Homicide (direct or indirectly such as assassination, etc.), murder attempt, inflicted injuries, inflicted serious injuries, rape/sodomy, harassment, kidnapping.

\subsection{The Image Used has Two Essential Elements of Persuasion and Propaganda.}

Crime can be defined and carries various meaning but all in all, it comes back to having a negative connotation. Regarding Dewan Bahasa dan Pustaka (The Institute of Language and Literature) dictionary the fourth revised edition, crime is specified as an unlawful or illicit act or evil deeds under the nation's legislation, for example; stealing; robbing; killing; raping; pocketing and such. Crime is as horrendous as an enemy can be for an individual as well as a society of all races and religions. The crime doers have not classed bases explicitly on the domestic factors of age, gender, race, or religion. The reality is, it is widely accepted the fact that all religions forbid criminal acts; however, to some people, rules are always made to be broken. In Islam, any type of crime is prohibited. This is proven in Verse 90 of Surah Al-Nahl, "Allah commands justice, the doing of good, and liberality to kith and kin, and He forbids all shameful deeds, and injustice and rebellion: He instructs you, that ye may receive admonition " (Mohd Asri Abdullah, 2009). The impact of the crime occurrences has raised concern and fear in society.

eISSN: 2398-4287 ( 2020. The Authors. Published for AMER ABRA cE-Bs by e-International Publishing House, Ltd., UK. This is an open access article under the CC BYNC-ND license (http://creativecommons.org/licenses/by-nc-nd/4.0/). Peer-review under responsibility of AMER (Association of Malaysian Environment-Behaviour Researchers), ABRA (Association of Behavioural Researchers on Asians) and cE-Bs (Centre for Environment-Behaviour Studies), Faculty of Architecture, Planning \& Surveying, Universiti Teknologi MARA, Malaysia.

DOI: https://doi.org/10.21834/ebpj.v5iSI1.2310 
Additionally, Senator Dato Sri Idris Jalal has branded "crime is public enemy number one" in the "Di Luar Lingkungan " program aired on channel TV1. Crime image is categorized in photojournalism. This type of image is usually taken on the same day of crime occurrence. Sadness, fear, horror, frustration, pity, and other sentiments are present in the public's mind when they watch the crime images strewn over the front page of newspapers. It can be said that the frequency of these incidents is daily.

Photographers involved are in charge of obtaining the right images. Even though there are intimidating or unnerving happenings at the crime scene, the images will first be separated and extracted by the auditors to make it acceptable to the public. Numerous negative impacts originate from the respective crimes. It starts from a small offense and expanding to greater transgression until it reaches the point where it is uncontrollable and affecting its surroundings. Criminal activities with its parasitic trait will continue to distort the peace in the community and life in general. As evidenced in the Harian Metro newspaper, it was found that crime cases involved violent acts such as rape, sodomy, and incest increase for the past five years. Based on the crime statistics report in 2005, it was stated that 2,427 cases are increasing to 2,943 cases in 2006, while in 2007, the number of the case reported surged to 3,689 and there is no indication of decrement in 2008 was reported to accumulate 3,986 cases. This continues until 2009 where it was stated that it had reached 4,238 cases which is a critical point. The overall claims within these five years are totalled to 17,283 cases (Harian Metro, 2011).

There are various negative impacts derived from indiscretion. From small scale offense to large, the uncontrollable scale will lead to the destruction of the public and the surroundings. The parasitic value of criminal acts will gradually obliterate the sense of peace in the hearts of society. The strongest impression is when crimes are PDRM's ' core business' (Polis DiRaja Malaysia, 2009).

\subsection{Understanding Mass Persuasion and Propaganda}

Propaganda and persuasion word is synonymous with media at present, a form of communication that used and found in the media: television, internet, radio, newspapers, magazines, and so on. The word propaganda at present is often overshadowed by the negative connotation and describes a thing or event exaggeratedly. The word comes from the Latin word propaganda of ' propagare ', which means to spread and disseminate Jowett and Donnell (2006). Even Romarheim (2005) viewed that the term propaganda itself is the cause of a dispute and controversy, even after World War II, propaganda has been widely used in daily life using the language or slogan and this act would eventually bring an adverse effect and it also a better impact.

According to Lisa Kelly in her journal, an act of propaganda is to persuade where it uses symbols, images, and slogans. She also stated that propaganda is one idea that is used to promote the use of an event that is organized and carefully planned to influence the attitudes, perceptions, and actions of target individuals or communities. For such purpose of persuasion, Walton (1997) described that the persuasion as one of the important aspects of mass communication in the present and functions are also available in propaganda where the method also involves the use of propaganda or the aspect of persuasion. Persuasion according to Simons, Morreale, and Gronbeck (2001) in their book titled Persuasion in society, is a form of human communication designed to influence a decision of autonomy and influence the actions of others. Persuasion also influences the nature of the medium that aims to change the way a person thinks, feels, and acts in the decision-making. Propaganda and persuasion does have similarities in terms of function and role; however, there is no other writer or researcher that can distinguish the difference between propaganda and persuasion (Jowett and Donnell, 2006).

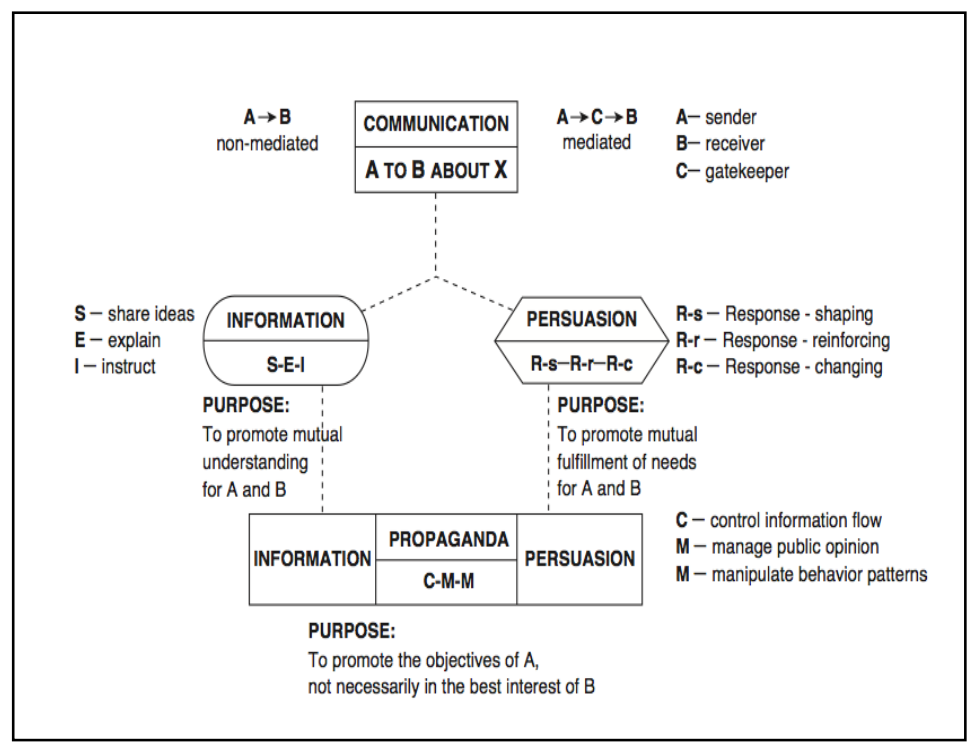

Figure 1: The Jowet And Donnell Purpose Of Model Propaganda (Note: Propaganda and Persuasion by Garth S. Jowett and Victoria O'Donnell (2006) 


\subsection{Persuasion and Propaganda as a Form of Communication}

Persuasion and propaganda have existed as an effective medium of communication in the world of media communication in ancient times until the present. The ability to achieve the desired objectives makes it an essential medium that is widely used in communication media today. Walton (1997) explained critical aspects of propaganda is that it communicates to reach and influence a crowd thinking its application is said to influence such thinking, changing the views and perceptions of society on the issues raised. This can be seen through the use of propaganda in newspaper publishing where it will be inserted using the word, slogan, illustration, or photography images. Higashinakano Shudo (2008) stated that the newspaper published in large quantities when compared with the magazine or a book because it has several users, and this medium would indeed be infused with the use of propaganda filled with a variety of purposes and agendas to communicate with readers and the community at large. Jowett and Donnell (2006) described the propaganda and persuasion as a form of communication in which it is used and communicated through the tools of technology to transmit and deliver information to the public in a speedy pace period.

\subsection{The Role of Visual Image in Persuasion and Propaganda}

Communication at present is not limited to one form only because of various communication mediums created by the invention of more sophisticated and human expertise evidenced in science and technology. Progress in line with the booming world civilization gave many benefits and convenience to humankind. The closest model to be associated with the presence of such modern development is photography which was created for the use of cameras to record images of interest. From the beginning of the creation of the camera, it has brought us to a form of communication in a visual form. The way of visual communication is becoming more and more frantic as more and more people who make this medium as an intermediary to communicate.

According to Suh and Biernatzki (1999), the use of visual images as a medium of communication is essential because it has the features of persuasion and propaganda, and functions that could attract the attention of the community and influence their decisions. Although the picture does not speak verbally, its impact and significance can convey deep meaning and message more than words. Not surprisingly, the media has drawn the interest of the community to be utilized in everyday life. As is well known, the use of images has dominated the world of today where we can see it through the internet, televisions, newspapers, magazines, and various other mediums.

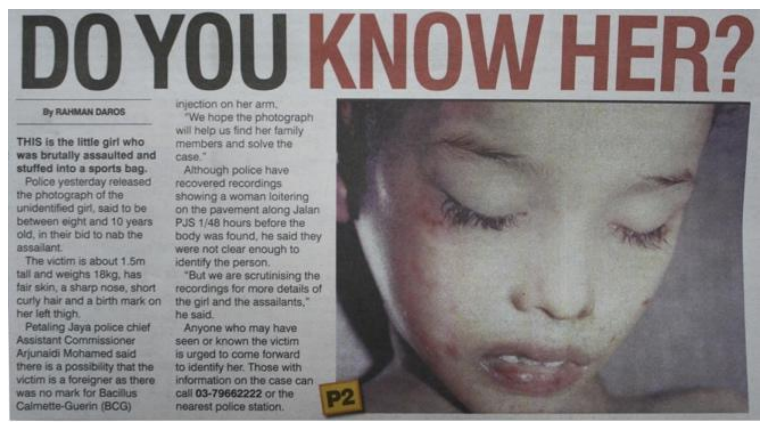

Figure 2: Do you know her? ( Source: The Malay Mail, 19 September 2007, Wednesday)

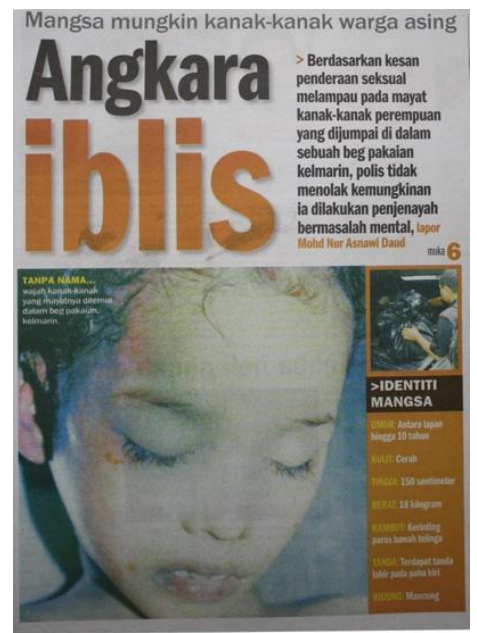

Figure 3: Angkara Iblis (Source: Harian Metro, 19 September 2007, Wednesday)

The Picture is of an effective communication medium in conveying information to each member of the community. Notably in the press, it is enough to show how powerful a picture where it would adorn the front pages of newspapers. This indicates that the 
picture has won the trust in the community to deliver an essential message to them. Each image certainly has the characteristics of persuasion and propaganda. This view is also has been proved by the writing of Suh and Biernatzki (1999) which claimed that the function a compelling image in giving effect to the community in which the image can persuade, influence, encourage individual thinking about a particular issue raised. It is also due to the function of the image that can permeate the thinking of individuals and the effect of long-term memory.

For each picture featured in the newspaper, their role is to function as persuasion and propaganda. Image crime as the main topic of this study, the purpose of the image is displayed to the public is to give a lesson to the community. Besides that, it works to persuade, to change the perception, influence public thinking related to the issues raised. In terms of propaganda, the selections of these images are very carefully made and have to go through various stages. The photos displayed crimes are said to have propaganda value due to interest readers of the issues presented. Persuasion and propaganda both are essential elements that can give a significant impact on the readers on how they evaluate the image.

\subsection{Conclusion}

In conclusion, the understanding of persuasive and propaganda functions should be understood in depth by photographers, auditors as these individuals are the main distributors of information or images to the public. The use of this image has attracted considerable attention from members of the community so much that it appears to provide the desired information. In this issue, the picture plays a vital role in attracting the public to help in channelling information about the case equally.

\section{Acknowledgments}

We would like to acknowledge our research partners namely Community of Research (CoRE) UiTM Malaysia, Institute of Research Management (IRMI) UiTM Malaysia, and Public Art Creative Aesthetic Quality (PACAQ/ EK Tier 5) UiTM Cawangan Melaka for supporting this study.

\section{References}

Azahari, M.H.(2011). Photography Its Significance Strands and Values in Education. Shah Alam: University Publication Centre UiTM.

A.Borchers, T. (2005). Persuasion In The Media Age Second Edition. McGraw- ${ }^{\circ}$-Hill Companies, Inc..

Barret, T. (2006). Criticizing Photographs An Introduction To Understanding Images. New York: McGraw- ${ }^{\circ}-$ Hill Companies, Inc.

Ismail, A. I., \& Azahari, M.H. (2010). An Interpretation of Photography as an Art and Communication. IEEE

Jowett, G.S, \& O'Donnell, V. (2012). Propaganda \& Persuasion. United State Of America: SAGE Publication Ltd.

Lester, P. M. (2003). Visual Communication: Images With Messages. United States Of America: Wadsworth, A Division Of Thomson Learning, Inc.

Novitz, D. (1997). Pictures and Their Use In Communication. Belgium: Martinus Nijhoff The Hague Netherlands.

Harris, R.C., \& Lester, P. M. (2002). Visual Journalism A Guide For New Media Professionals. California State: A Pearson Education Company.

Smeth, K., Moriarty, S., Barbatsis, G., \& Kenny, K. (2005). Hand Book of Visual Communication: Theory, Methods, and Media. United States of America: Lawrence Erlbaum Associates, Inc.

Shudo, H. (2008). Top- ${ }^{\circ}$ C-Secret Chinese Nationalist Documents Reveal The Truth About The Nanking Incident. Tokyo: Society For The Dissemination of Historical Fact. 